\title{
Fabrication, Mercury Intrusion Porosimetry Characterization and In Vitro Qualitative Analysis of Biocompatibility of Various Porosities Polycaprolactone Scaffolds
}

\author{
Tania Limongi ${ }^{1 *}$, Andrea Giugni ${ }^{1}$, Hua Tan ${ }^{2}$, Ebtihaj M Bukhari ${ }^{3}$, Bruno Torre', Marco Allione ${ }^{1}$, Monica Marini ${ }^{1}$, Luca Tirinato' ${ }^{1}$, Gobind Das ${ }^{1}$, \\ Manola Moretti ${ }^{1}$, Andrea Falqui ${ }^{4}$ and Enzo di Fabrizio ${ }^{1}$
}

${ }^{1}$ SMILEs Lab, Physical Science and Engineering (PSE) and Biological and Environmental Science and Engineering (BESE) Divisions, King Abdullah University of Science and Technology, Thuwal 23955-6900, Kingdom of Saudi Arabia

${ }^{2}$ Analytical Core Labs, King Abdullah University of Science and Technology, Thuwal 23955-6900, Kingdom of Saudi Arabia

${ }^{3}$ Imaging and Characterization Core Lab, King Abdullah University of Science and Technology, Thuwal 23955-6900, Kingdom of Saudi Arabia

${ }^{4}$ NABLA Lab, BESE Division, King Abdullah University of Science and Technology, Thuwal 23955-6900, Kingdom of Saudi Arabia

\begin{abstract}
In order to develop surfaces with improved cell culture biocompatibility, we optimized a solvent-casting and particulate-leaching fabrication technique to create porous three-dimensional polycaprolactone scaffolds. These biocompatible porous surfaces were realized by means of $\mathrm{NaCl}$ particles as porogen; salt leaching by immersion in distilled water created porosity and pore interconnectivity in the material. Scanning electron microscopy and mercury intrusion porosimetry were used for the measurement of porosity, pore size distribution, permeability and compressibility. To evaluate scaffold biocompatibility, fibroblasts were cultured on the porous surfaces and confocal immunofluorescence characterization indicated that they were effective for in vitro cell culture and practical tissue engineering applications.
\end{abstract}

Keywords: Tissue engineering; Biocompatibility; Biomaterials; Porosity; Porogens; Polycaprolactone; Fibroblasts

Abbreviations: 3D: Three-Dimensional; ECM: Extracellular Matrix; PGA: Polyglycolic Acid; PLA: Polylactic Acid; PLLA: Poly(L-Lactide); PLGA: Poly(D,L-Lactide-Co-Glycolide); PDO: Polydioxanone; PCL: Polycaprolactone; THF: Tetrahydrofuran; MIP: Mercury Intrusion Porosimetry; SEM: Scanning Electron Microscopy; RT: Room Temperature; O.S.: Opening Size; FBS: Fetal Bovine Serum; PBS: Phosphate Buffered Saline; BSA: Bovine Serum Albumin

\section{Introduction}

The continuing demand for tissue and organ substitutes is conferring to tissue engineering the potential to provide surgeons and patients with more translational individualized solutions for injury trauma, disease or simple senescent processes. In most cases using three-dimensional (3D) scaffolds to assist cells grow and development, regenerative medicine upgrades the condition of patients' life by engineering and/ or replacing damaged tissue and organs as blood vessels $[1,2]$, skin $[3,4]$, cornea [5,6], vertebrae [7], tendon and nerve [8,9], trachea, esophagus [10] and many other types of tissue. Tissue engineers' work on growing replacement tissues and organs for transplantation into patients and one of the biggest challenges for them is the realization of fully biocompatible scaffolds in order to ensure the most physiological crosstalk between surfaces and cells. Tissues are mainly constituted by the Extracellular Matrix (ECM), a complex network of macromolecules, glycoproteins including fibronectin, laminin and proteoglycans and fibrous proteins as elastin and collagens [11].

A well-designed 3D tissue engineered scaffold should successfully guide cell proliferation, physiological ECM synthesis, adhesion and differentiation by ensuring nutrients and oxygen diffusion and, at the same time, elimination of catabolites. Beyond the biocompatibility, to guarantee successful in vitro tissue regrow and in vivo integration and reformation, scaffolds must be characterized by an accessible geometry. To realize homogenous cell infiltration, invasion and migration into the scaffolds, pores and their interconnectivity, must be optimized to assure a strong cell-biomaterial interface and by avoiding cells detachment. To provide a satisfying cellular proliferation, optimal diffusion of growing factors, nutrients, gasses and an efficient disposal of wasted products, scaffolds should be designed by means of an interconnected porous structure by optimizing mechanical function and mass-transport requirements. In details, pores provide the optimal background for cells proliferation and, by promoting the physiological interactions between the cells and the ECM, they result in essential tools for successful tissue regeneration.

The sizes and the distribution of the void spaces in porous biomaterials relates to specific function; in tissue engineering macropores $(50 \mathrm{~nm}-300 \mu \mathrm{m})$ are useful for mechanical function and cell and tissue penetration while micropores $(<2 \mathrm{~nm})$ and mesopores $(2-50 \mathrm{~nm})$ contribute to solutes diffusion $[12,13]$.

Porous scaffolds have been extensively used in tissue engineering applications, for organ vascularization and for regrowth host tissues [14]. The most effective grade of porosity, for each tissue regeneration applications, is surely related to the tissue and organ type to reproduce; all the different components constituting the cellular microenvironment such as cell phenotypic expression, dimension and ECM production must be strictly considered.

${ }^{*}$ Corresponding author: Dr. Tania Limongi, Physical Science and Engineering (PSE) Division, Biological and Environmental Sciences and Engineering (BESE) Division, King Abdullah University of Science and Technology Bldg. 2, 4th floor, Desk 4315-WS09, Desert side, Thuwal, 23955 -6900, Kingdom of Saudi Arabia Tel: 9660128082303; E-mail: tania.limongi@kaust.edu.sa

Received October 20, 2015; Accepted November 25, 2015; Published December 02, 2015

Citation: Limongi T, Giugni A, Tan H, Bukhari EM, Torre B et al. (2015) Fabrication, Mercury Intrusion Porosimetry Characterization and In Vitro Qualitative Analysis of Biocompatibility of Various Porosities Polycaprolactone Scaffolds. J Tissue Sci Eng 6: 159. doi:10.4172/2157-7552.1000159

Copyright: ( 2015 Limongi T, et al. This is an open-access article distributed under the terms of the Creative Commons Attribution License, which permits unrestricted use, distribution, and reproduction in any medium, provided the original author and source are credited. 
Citation: Limongi T, Giugni A, Tan H, Bukhari EM, Torre B, et al. (2015) Fabrication, Mercury Intrusion Porosimetry Characterization and In Vitro Qualitative Analysis of Biocompatibility of Various Porosities Polycaprolactone Scaffolds. J Tissue Sci Eng 6: 159. doi:10.4172/21577552.1000159

Page 2 of 6

Since optimal pore sizes vary for different cells and tissues [15], porous scaffolds must be realized with specific, porosity and surface-area-to-volume ratio. Synthetic biodegradable polymers as Polyglycolic Acid (PGA), Polylactic Acid (PLA), Poly(L-lactide) (PLLA), Poly(d,l-lactide-co-glycolide) (PLGA), Polydioxanone (PDO) and Polycaprolactone (PCL) by having optimal tensile strength, and predictable degradation rate, are successfully used as porous scaffolding materials [16-21]

Several different technological approaches have been used to realized 3D porous scaffolds using synthetic biopolymers, these include electrospinning [22], gas foaming [23], freeze drying [18], phase separation [24], porogen leaching, fiber bonding [25], three-dimensional printing and fused deposition modeling [26-28]. Doubtless each of the above-mentioned solutions has its advantage, but, for an exact control over porosity and pore diameter, molding fabrication and porogen leaching technique together represent a fast and economic solution for controlling biocompatible materials porosity $[29,30]$. Solution casting/ particulate leaching, by including casting of the polymer/porogen solution followed by solvent evaporation and removal of the integrated porogen via aqueous washing methods, can be applied to a wide range of biopolymers to design porosity into biocompatible scaffolds. Pores or channels are created using porogens, such as salts and sugar crystals, soft paraffin and biopolymeric spheres [31-33].

This article reported the preparation of porous PCL scaffolds by a $\mathrm{NaCl}$ salt-leached method using tetrahydrofuran (THF) as a solvent.
PCL was chosen among the aforementioned biocompatible and biodegradable polymers because it is characterized by having a melting point range of $59-64^{\circ} \mathrm{C}$ and a tailorable degradation kinetics slower than PGA and Poly(D,L-lactide) [34]. Another important physicochemical property of PCL is its hydrophobicity since it allowed us to seed cells using a single drop of medium by inoculating them on a particular area on the surface of the scaffold.

We focused on the different fabrication steps and on the characterization of the effect of various $\mathrm{NaCl}$ crystal sizes on the final structure by means of mercury intrusion porosimetry (MIP) and scanning electron microscopy (SEM). The biocompatibility was investigated by seeding NIH-3T3 fibroblasts on the porous scaffolds and then incubating for 7 days before assessing cell attachment and growth using confocal microscopy.

\section{Materials and Method}

\section{Substrate preparation}

PCL scaffolds were produced by means of solvent casting/particulate leaching technique. Polymer pellets ( $\mathrm{Mn} \sim 80,000$, pellets, SigmaAldrich, 440744) were dissolved 5\% wt/wt in tetrahydrofuran (34865 Sigma-Aldrich) by stirring for about 4 hours at room temperature (RT). To create the pores into the matrix, sodium chloride crystals (SigmaAldrich, S9888) were employed as porogen, sieved using SigmaAldrich cell dissociation sieves (Figure 1A-1C) (CD-1 Sigma) with specific Opening Size (O.S.) (140 and $380 \mu \mathrm{m}$, Figure 2B). The viscous
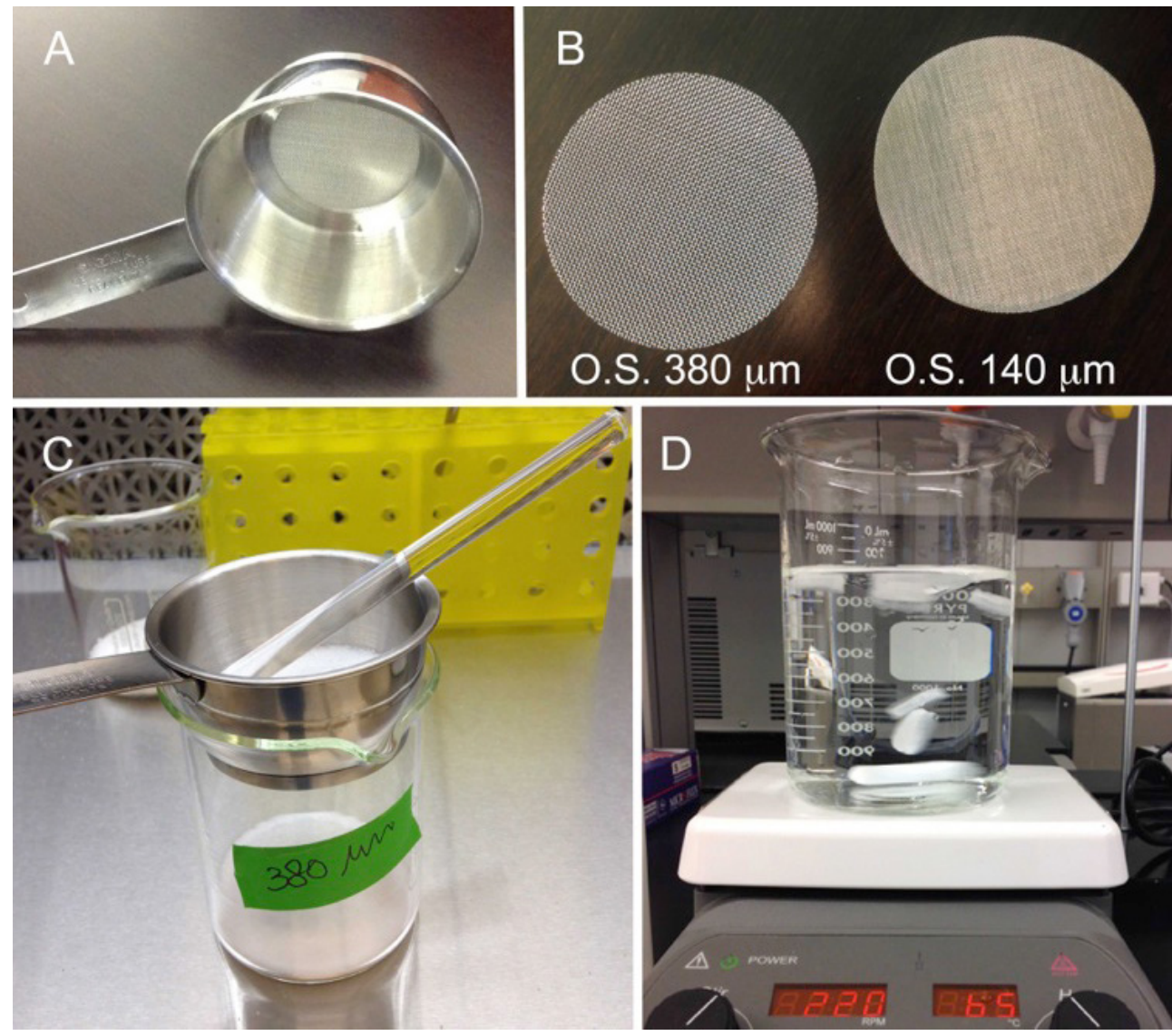

Figure 1: Particulate-leaching techniques materials and methods. The process is easy to carry out: $\mathrm{NaCl}$ crystals were used to create the pores, and the grinding (A) and sieving (B and $\mathrm{C}$ ) of sodium chloride resulted in uniform particulates. A PCL, THF solution was casted into the salt-filled glass mold and after the evaporation of the solvent; the salt crystals are leached away using distilled hot water (D). 
Citation: Limongi T, Giugni A, Tan H, Bukhari EM, Torre B, et al. (2015) Fabrication, Mercury Intrusion Porosimetry Characterization and In Vitro Qualitative Analysis of Biocompatibility of Various Porosities Polycaprolactone Scaffolds. J Tissue Sci Eng 6: 159. doi:10.4172/21577552.1000159

Page 3 of 6
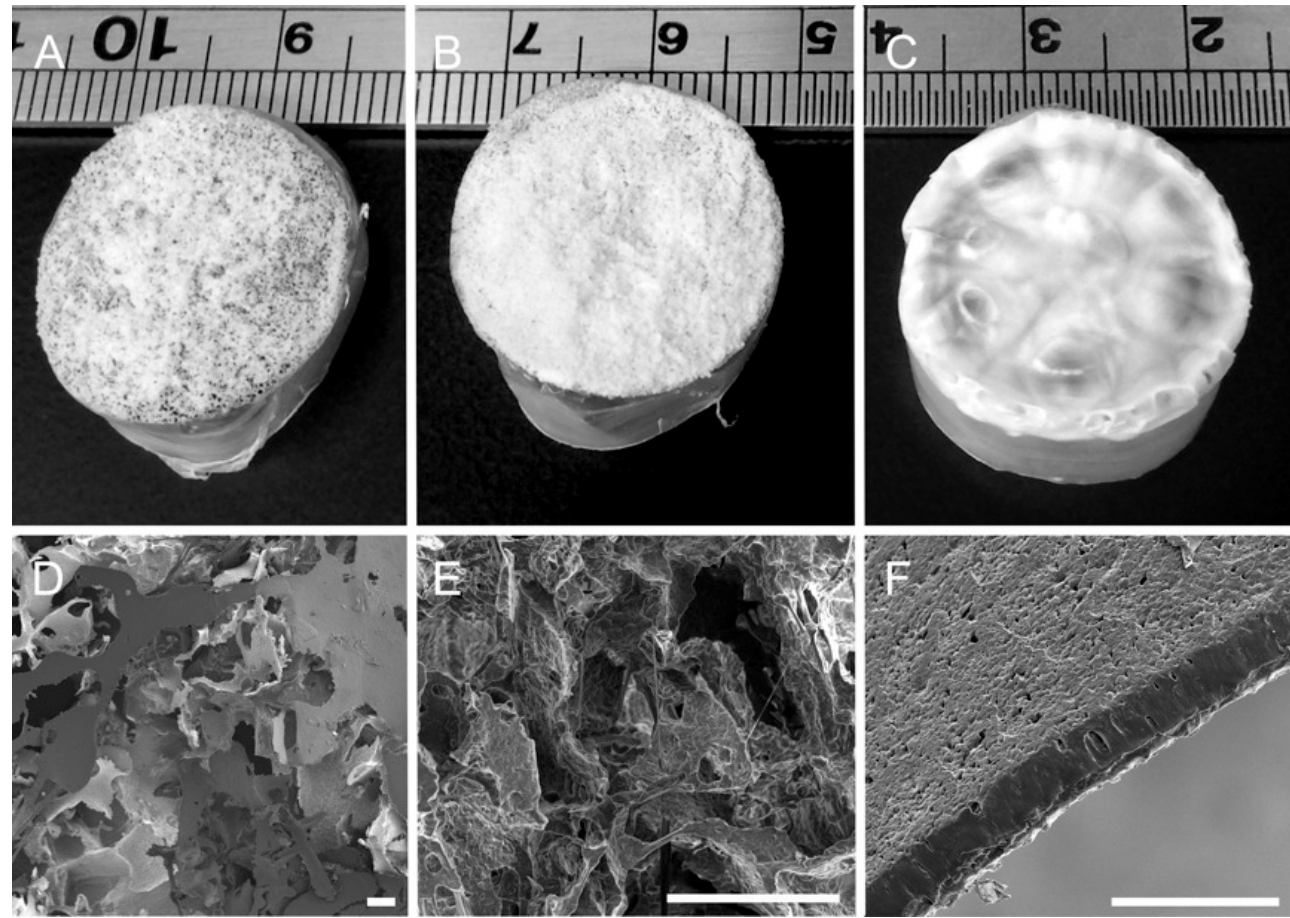

Figure 2: Photograph and SEM images of the PCL porous scaffolds. The substrates were produced by using NaCl/PCL (30 \% wt/v) composition realized with sieved salt crystals with diameters between 140-380 $\mu \mathrm{m}(\mathrm{A}, \mathrm{D})$, minus of $140 \mu \mathrm{m}(\mathrm{B}, \mathrm{E})$ and $\mathrm{PCL}$ without salts $(C, F)$. In $A, B$ and $C$ ruler represented cm; in $D$, E, F scale bars equals $100 \mu \mathrm{m}$.

polymer solution was then cast in $10 \mathrm{ml}$ pyrex low form glass molds $(2$ $\mathrm{cm}$ diameter) containing the salts $(30 \% \mathrm{wt} / \mathrm{vol})$ and solvent was let to evaporate overnight, at RT, in a chemistry fume hood.

The polymer/salt composite was then leached in hot (about $40^{\circ} \mathrm{C}$ degrees) Milli-Q water, with water changes every 12 hours, for three days to remove the porogens (Figure 1D). Scaffolds were then dried in an oven at $40^{\circ} \mathrm{C}$ for 24 hours and stored in a desiccator. Each PCL substrates $\left(0.7 \mathrm{~cm}^{2}\right)$ were placed in a 12 wells plate, sterilized by immersion in ethanol, washed twice in sterile water, dried in a laminar flow hood and further sterilized by UV irradiation for 2 hours. Substrates were let float face down on the DMEM/F12 plus 10\% fetal bovine serum (FBS) solution for 7 days in a cell culture incubator $\left(37^{\circ} \mathrm{C}, 5 \% \mathrm{CO}_{2}, 95 \%\right.$ humidity). Before plating the cells, the medium was removed and substrates were washed and let dry in the biological cabinet for a couple of hours.

\section{Cells seeding}

NIH/3T3 mouse embryonic fibroblast cells were cultured in T-75 flasks with DMEM media with high Glucose (GIBCO, 12800-017), supplemented with 10\% FBS (GIBCO, 1600-044) and penicillin $100 \mathrm{U} /$ $\mathrm{ml}$ (Cellgro, 30.001.C1). They were incubated at $37^{\circ} \mathrm{C}$ in a humidified $5 \%$ $\mathrm{CO}_{2}$ incubator until reached $70-80 \%$ confluent. Cells were trypsinized (Cellgro, 25-052-C1), harvested, diluted 1:1 with fresh medium and counted ( $8.5 \times 10^{5}$ cells) using a Scepter cell counter (Millipore). $4 \times 10^{4}$ cells were seeded on each scaffold in a single $50 \mu \mathrm{L}$ drop of medium and after 4 hours, fresh medium was added to each substrate. All cells were incubated and maintained in a humidified atmosphere at $37^{\circ} \mathrm{C}$ and $5 \%$ $\mathrm{CO}_{2}$ for 7 days.

\section{Scaffolds characterization}

Scanning electron microscopy: Scaffolds were observed using a
Quanta 200 FEG scanning electron microscope. The cross-sections of the PCL porous surfaces were coated with $10 \mathrm{~nm}$ of Iridium by a Q150T sputter coater (Quorum Technologies Ltd.) before observation.

Porosimetry: Mercury intrusion porosimetry (AutoPore IV 9500, Micromeritics, USA) was used to determine pore size distribution and porosity. The samples were first evacuated to a pressure of 0.5 psia in order to remove physisorbed gasses from the interior of the sample. Porosimetry experiments were conducted with an equilibration time of $10 \mathrm{~s}$, the pressure was increased incrementally from 0.5 psia to 60000 psia, and then the pressure was decreased incrementally back to atmospheric pressure. For each sample, about $0.05 \mathrm{~g}$ of material was analyzed by using a $3 \mathrm{cc}$ penetrometer.

Immunocytochemistry staining: Cytoskeleton organization was visualized using an actin cytoskeleton and focal adhesion staining kit (Millipore, FAK100) according to the manufacturer's instruction. The cells were washed in $1 \mathrm{X}$ phosphate buffered saline (PBS) (Fisher Scientific, 108294), fixed in a 4\% paraformaldehyde (EMS, 15710), in 1 $\mathrm{X}$ PBS solution for $20 \mathrm{~min}$ and permeabilized with $0.1 \%$ Triton X-100 (Acros-Organics, 9002-93-1) for $5 \mathrm{~min}$. Blocking solution 1\% bovine serum albumin (BSA) in PBS (Thermo Scientific, 37525) was applied for $30 \mathrm{~min}$, and the cells were rinsed three times with $1 \mathrm{X}$ PBS. Then, cells were incubated with primary antibody anti-Vinculin (1:200) for one hour, followed by washing three times ( $5 \mathrm{~min}$ each). For double labeling secondary antibody FITC-conjugated (1:100) (Millipore, AP124F) was incubated simultaneously with TRITC- conjugated Phalloidin (1:300) in PBS for one hour, followed by washing cells three times (5-10 minutes each) with $1 \mathrm{x}$ wash buffer. Nuclei were stained by incubating cells with DAPI (Invitrogen, D1306) for 5 minutes at RT, followed by washing cells three times ( 5 minutes each) with $1 \mathrm{X}$ wash buffer. 
Citation: Limongi T, Giugni A, Tan H, Bukhari EM, Torre B, et al. (2015) Fabrication, Mercury Intrusion Porosimetry Characterization and In Vitro Qualitative Analysis of Biocompatibility of Various Porosities Polycaprolactone Scaffolds. J Tissue Sci Eng 6: 159. doi:10.4172/21577552.1000159

Page 4 of 6

Laser scanning confocal microscopy: Upright LSM 710 Zeiss Confocal Microscopy was used to visualized fluorescence images with a 40X W (Plan-Apochromat, NA 1.0) water-immersion objective. Images were acquired in sequential acquisition mode and processed using Adobe Photoshop CS6 software.

\section{Results}

Three types of scaffolds with different pore sizes were produced by using solvent casting/particulate leaching technique with sieved salt crystals with diameters comprise between 140-380 $\mu \mathrm{m}$ (Figure $2 \mathrm{~A}$ ), minus of $140 \mu \mathrm{m}$ (Figure 2B) and PCL without salts (Figure 2C). According to SEM micrographs by using porogens the substrates resulted characterized by interconnected pore structures both for salts of dimensions comprised in a range of 140-380 $\mu \mathrm{m}$ (Figure 2D) and minus of $140 \mu \mathrm{m}$ (Figure 2E). Scaffolds realized without salts exhibited a well-defined compact structure (Figure 2F) with small but numerous pores.

MIP results confirmed SEM imaging; in Table 1 is summarized as substrate realized without salt had the highest total pore area $(40.26$ $\left.\mathrm{m}^{2} / \mathrm{g}\right)$ but the smallest pore characteristic length $(25.63 \mu \mathrm{m})$ and so the lowest porosity $(22.76 \%)$. Referring to substrates realized using different porogen diameters, their porosity was remarkable higher than no salt ones, but comparable between themselves, $82.47 \%$ using smaller crystal salts and $78.05 \%$ for the biggest ones. Although the porosity of the two types of scaffold realized with sodium chloride salts is almost the same, the permeability is greater in the substrates made with crystals of size between 140 and $380 \mu \mathrm{m}$ because their pores are less (total pore area, $\left.4.2 \mathrm{~m}^{2} / \mathrm{g}\right)$ but larger $(189 \mu \mathrm{m})$. Permeability is also affected by

\begin{tabular}{|l|c|c|c|c|}
\hline \multicolumn{1}{|c|}{ Content } & No salt & $<140 \mu \mathrm{m}$ & $140-380 \mu \mathrm{m}$ & $\mathrm{UM}$ \\
\hline Intrusion Data Summary & & & & \\
\hline Total Intrusion Volume & 0.30 & 3.79 & 3.31 & $\mathrm{~mL} / \mathrm{g}$ \\
\hline Total Pore Area & 40.26 & 25.06 & 4.20 & $\mathrm{~m} / \mathrm{g}$ \\
\hline Bulk Density at 0.52 psia & 0.75 & 0.23 & 0.24 & $\mathrm{~g} / \mathrm{mL}$ \\
\hline Apparent (skeletal) Density & 0.97 & 1.24 & 1.07 & $\mathrm{~g} / \mathrm{mL}$ \\
\hline Porosity & 22.76 & 82.47 & 78.05 & $\%$ \\
\hline Pore Structure Summary & & & & \\
\hline Threshold Pressure: & 7.06 & 2.37 & 0.96 & $\mathrm{psia}$ \\
\hline Characteristic length & 25.63 & 76.46 & 189.07 & $\mu \mathrm{m}$ \\
\hline Permeability & 0.42 & 57.53 & 252.90 & darcy \\
\hline Tortuosity & 13.66 & 2.53 & 1.77 & \\
\hline
\end{tabular}

Table 1: Most important output data of mercury intrusion porosimetry analysis. tortuosity, the ratio of actual distance travelled between two points to the minimum distance between the same two point [35], and MIP showed that it decreased starting from scaffold realized without $\mathrm{NaCl}$ salts and considering than medium and small porogens respectively $13.66,2.53,1.77$.

In Figure 3A, in the graphical form, the volume of mercury intruded into each gram of sample as a function of pore diameter was presented; referring to substrates realized using different porogen diameters, their porosity was remarkable higher (blue and black lines) than those realized without $\mathrm{NaCl}$ crystals (red line), but comparable between themselves. Figure $3 \mathrm{~B}$ shows as each type of sample realized with salt leaching was characterized by a particular size of pores, about $200 \mu \mathrm{m}$ (blue line) for biggest salt crystals, ranging between 140 to 380 $\mu \mathrm{m}$, and about $80 \mu \mathrm{m}$, (black line) for the smallest sieved $\mathrm{NaCl}$ salts $(<140 \mu \mathrm{m})$. Regarding the class of pores with diameter minus of $0.1 \mu \mathrm{m}$, MIP analysis allowed us to conclude that their presence was not related to the use of salt in the manufacturing process but to the evaporation of the solvent used for melt PCL in the 3 different kinds of samples (Figure 3C).

Since biocompatibility, in terms of cell surface adhesion characterization, is a process also involving cytoskeletal reorganization of actin and vinculin [36-38] our in vitro tests, for the above three different type of scaffold, were performed using NIH/3T3 cells culture and, laser scanning confocal microscopy, to collect preliminary data on cell morphology and cell-scaffold interaction. Confocal microscopy qualitative analysis showed in Figure 4 that the 3 different surfaces were all biocompatible. Dense network of F-actin was observed on the fibroblasts cultured on the no salts scaffold (red signal in Figure 4, panels A-C), while parallel actin stress-fiber with lower density were observed on the elongated cells on the other 2 types of supports (red signal in Figure 4, panels D-I). Intensive vinculin signals (green color in Figure 4 can be found on membranes of cells growth on scaffolds but they were more numerous on those substrates without porogens since vinculin in focal adhesions (yellows dots in Figure 4 B, C, F and I) was located preferentially in correspondence of the edges of the pores present in the matrix of the scaffolds.

Cause of their pore characteristic length $(25.63 \mu \mathrm{m})$, porosity $(22.76$ $\mu \mathrm{m})$ and tortuosity $(13.66 \mu \mathrm{m})$, these low porosity scaffolds showed successful fibroblasts growth on them. The numerous but small pores of the surfaces realized without the use of $\mathrm{NaCl}$ porogens increased cells attachment and proliferation in respect of the situation observed for scaffolds with an average porosity of the $80 \%$ realized using medium
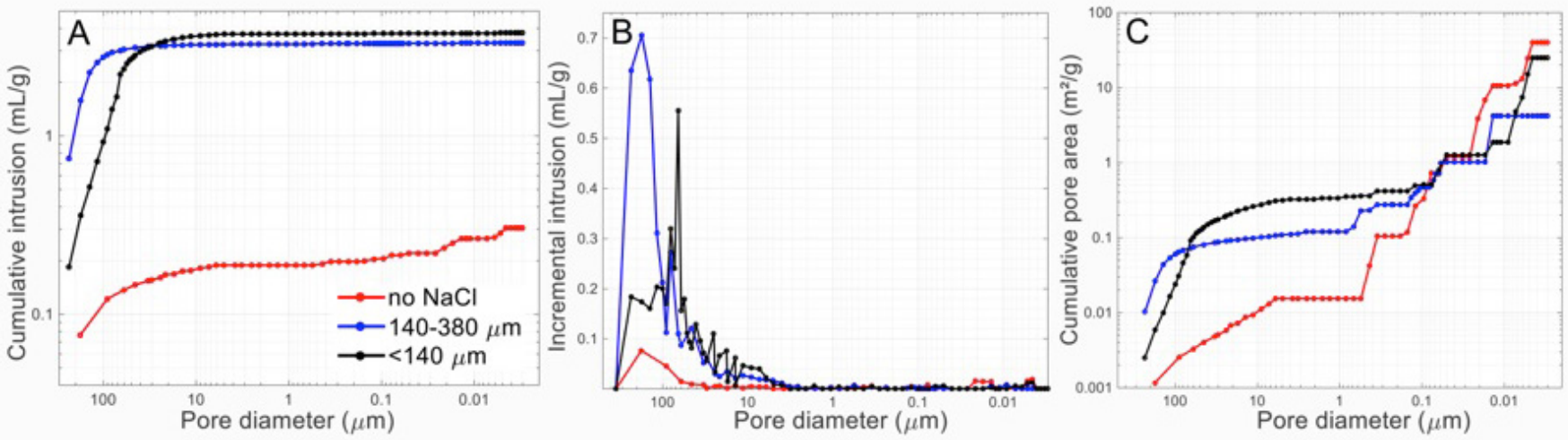

Figure 3: Cumulative (A) and differential $(B)$ intrusion curves and cumulative pore area $(\mathrm{C})$ as a function of pore diameter measured by mercury intrusion porosimetry. 
Citation: Limongi T, Giugni A, Tan H, Bukhari EM, Torre B, et al. (2015) Fabrication, Mercury Intrusion Porosimetry Characterization and In Vitro Qualitative Analysis of Biocompatibility of Various Porosities Polycaprolactone Scaffolds. J Tissue Sci Eng 6: 159. doi:10.4172/21577552.1000159
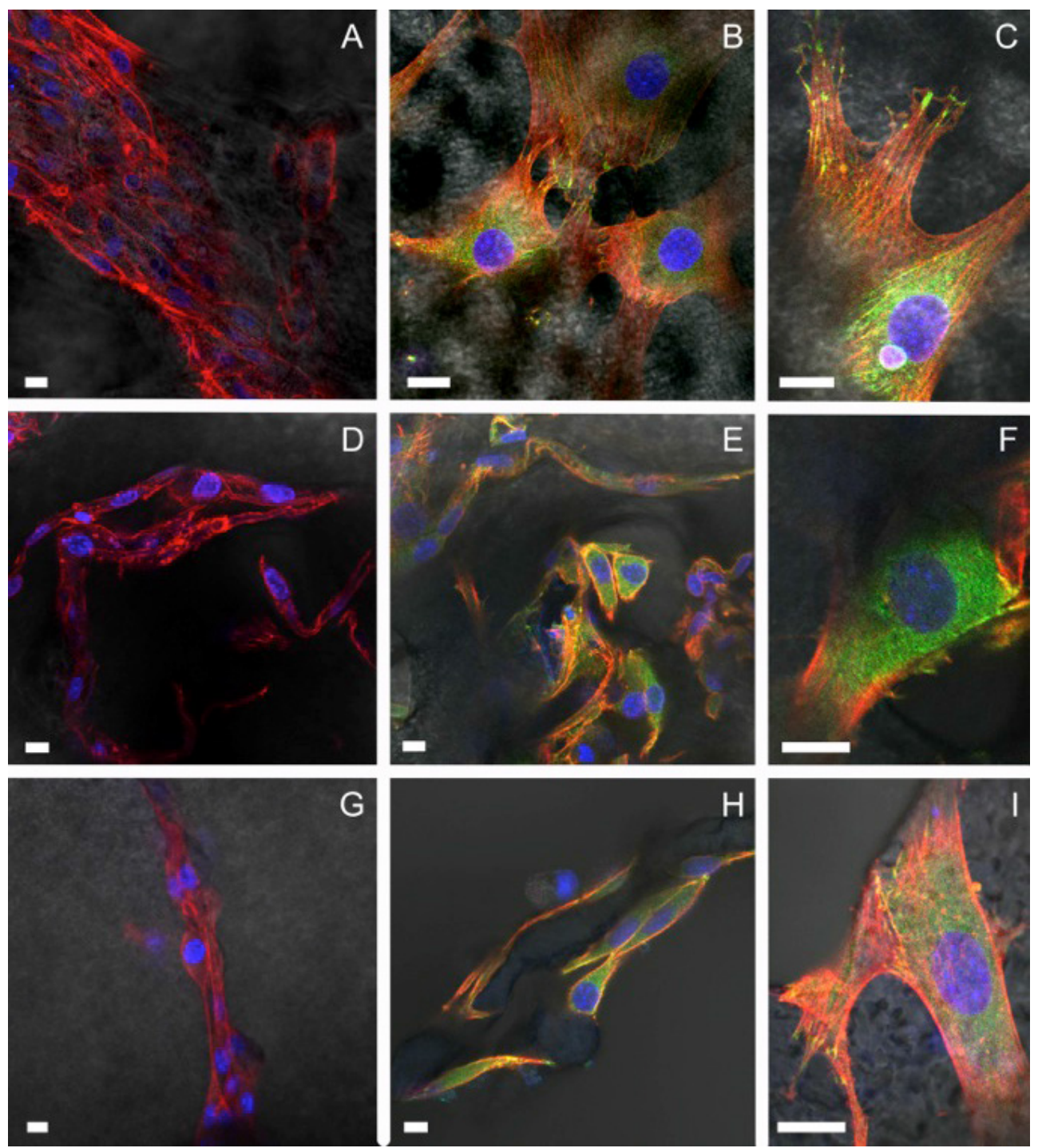

Figure 4: Confocal fluorescence microscopy of actin (red), vinculin (green) in focal adhesion (yellow in the merged channel) and nuclei (blue) in NIH-3T3 cells. In panels A, B, C was presented the imaging of cells plated on porous scaffold realized without porogens, in D, E, F cells seeded on substrates realized with crystal salts of dimensions $<140 \mu \mathrm{m}$ and in $\mathrm{G}, \mathrm{H}, \mathrm{I}$ images of cells on scaffold realized with porogens of dimension comprised between 140 and $380 \mu \mathrm{m}$. Scale bars equals $10 \mu \mathrm{m}$.

\section{$(<140 \mu \mathrm{m})$ (Figure $4 \mathrm{D}-4 \mathrm{~F})$ and wide salt crystals $(140-380 \mu \mathrm{m})$.}

These results indicated that growing fibroblasts on these biocompatible PCL porous scaffolds characterized by pores with a length comparable with the size of the same cells, promoted in vitro adhesion and proliferation. Based on qualitative analyses, the smaller pore size structure resulted more favorable than the other two because of its narrower pore size distribution and fewer large pores, which are surely more difficult to bridge.

To conclude solvent casting/particulate leaching, among the various scaffolding techniques, stands out for the possibility of simply and fast producing scaffolds with a variable pore interconnectivity degree by controlling composition, porosity and pores size. Finally, we propose these degradable porous scaffolds for future studies and for the realization of homogeneous cell/scaffold construct for regenerate tissues, by balancing temporary mechanical function with excellent mass transport simple tuning the degree of their porosity by changing the amount of salt and, the pore size, applying different salt crystals size.

\section{References}

1. Barreto-Ortiz SF, Fradkin J, Eoh J, Trivero J, Davenport M, Ginn B, et al. (2015) Fabrication of 3-dimensional multicellular microvascular structures. FASEB J 29:3302-3314

2. Wong MM, Hong X, Karamariti E, Hu Y, Xu Q (2015) Generation and Grafting of Tissue-engineered Vessels in a Mouse Model. J Vis Exp 97: e52565.

3. Shen YI, Song HH, Papa A, Burke J, Volk SW, Gerecht S (2015) Acellular Hydrogel for Regenerative Burn Wound Healing: Translation from a Porcine Model. J Invest Dermatol 135: 2519-2529.

4. Walmsley GG, Hu MS, Hong WX, Maan ZN, Lorenz HP, et al. (2015) A mouse fetal skin model of scarless wound repair. J Vis Exp 95: 52297.

5. Jay L, Bourget JM, Goyer B, Singh K, Brunette I, et al. (2015) Characterization of tissue-engineered posterior corneas using second- and third-harmonic generation microscopy. PloS one 10: e0125564.

6. Levis HJ, Kureshi AK, Massie I, Morgan L, Vernon AJ, et al. (2015) Tissue Engineering the Cornea: The Evolution of RAFT. J Funct Biomater 6: 50-65.

7. Gao C, Deng Y, Feng P, Mao Z, Li P, et al. (2014) Current progress in bioactive ceramic scaffolds for bone repair and regeneration. Int J Mol Sci 15: 4714-32. 
Citation: Limongi T, Giugni A, Tan H, Bukhari EM, Torre B, et al. (2015) Fabrication, Mercury Intrusion Porosimetry Characterization and In Vitro Qualitative Analysis of Biocompatibility of Various Porosities Polycaprolactone Scaffolds. J Tissue Sci Eng 6: 159. doi:10.4172/21577552.1000159

8. Li Y, Huang G, Zhang X, Wang L, Du Y, et al. (2014) Engineering cell alignment in vitro. Biotech Adv 32: 347-65

9. An J, Chua CK, Leong KF, Chen CH, Chen JP (2012) Solvent-free fabrication of three dimensionally aligned polycaprolactone microfibers for engineering of anisotropic tissues. Biomed microdevices 14:863-872.

10. Del Gaudio C, Baiguera S, Ajalloueian F, Bianco A, Macchiarini P (2014) Are synthetic scaffolds suitable for the development of clinical tissue-engineered tubular organs? J Biomed Mater Res A 102: 2427-2447.

11. Mouw JK, Ou G, Weaver VM (2014) Extracellular matrix assembly: a multiscale deconstruction. Nat Rev Mol Cell Biol 15: 771-785.

12. Nicodemus GD, Bryant SJ (2008) Cell encapsulation in biodegradable hydrogels for tissue engineering applications. Tissue Eng Part B Rev 14:149-

13. Lund AW, Yener B, Stegemann JP, Plopper GE (2009) The natural and engineered $3 D$ microenvironment as a regulatory cue during stem cell fate determination. Tissue Eng Part B Rev 15: 371-380.

14. Loh QL, Choong C (2013) Three-Dimensional Scaffolds for Tissue Engineering Applications: Role of Porosity and Pore Size. Tissue Eng Part B Rev 19: 485502

15. Bru auskait I, Bironait D, Bagdonas E, Bernotien E (2015) Scaffolds and cells for tissue regeneration: different scaffold pore sizes different cell effects. Cytotechnology DOI 10.1007/s10616-015-9895-4.

16. Mi HY, Jing X, Turng LS (2014) Fabrication of porous synthetic polymer scaffolds for tissue engineering. J Cell Plast 51: 165-196.

17. Almeida LR, Martins AR, Fernandes EM, Oliveira MB, Correlo VM, et al. (2013) New biotextiles for tissue engineering: Development, characterization and in vitro cellular viability. Acta Biomater 9: 8167-8181.

18. Haaparanta AM, Uppstu P, Hannula M, Ellä V, Rosling A, et al. (2015) Improved dimensional stability with bioactive glass fibre skeleton in poly(lactide-coglycolide) porous scaffolds for tissue engineering. Mater Sci Eng C 56: 457-66.

19. Oh SH, Park SC, Kim HK, Koh YJ, Lee JH, et al. (2011) Degradation Behavior of 3D Porous Polydioxanone-b-Polycaprolactone Scaffolds Fabricated Using the Melt-Molding Particulate-Leaching Method. J Biomater Sci Polym Ed 22: 225-237.

20. Jonnalagadda JB, Rivero IV (2014) Effect of cryomilling times on the resultan properties of porous biodegradable poly(e-caprolactone)/poly(glycolic acid) scaffolds for articular cartilage tissue engineering. J Mech Behav Biomed Mate 40: $33-41$

21. Shu XL, Shi QS, Xie XB, Huang XM, Chen YB. Preparation and characterization of a novel-PGA/-tricalcium phosphate composite for tissue engineering. Adv Mat Res 900: 306-311.

22. Ingavle GC, Leach JK (2014) Advancements in electrospinning of polymeric nanofibrous scaffolds for tissue engineering. Tissue Eng Part B Rev 20: 277 293.

23. Schliephake H, Vucak M, Boven J, Backhaus S, Annen T, et al. (2015) Solvent free production of porous PDLLA/calcium carbonate composite scaffolds improves the release of bone growth factors. J Oral Maxillofac Surg 19: 133141.

24. Liu X, Miller li AL, Waletzki BE, Yaszemski MJ, et al. (2015) Novel biodegradable poly(propylene fumarate)-co-poly(I-lactic acid) porous scaffolds fabricated by phase separation for tissue engineering applications. RSC Adv 5:21301-21309.
25. Caracciolo PC, Buffa F, Thomas V, Vohra YK, et al. (2011) Biodegradable polyurethanes: Comparative study of electrospun scaffolds and films. J App Polym Sci 121: 3292-3299.

26. Yang SS, Choi WH, Song BR, Jin H, Lee SJ, et al. (2015) Fabrication of an osteochondral graft with using a solid freeform fabrication system. J Tissue Eng Regen Med 12: 239-48.

27. Chia HN, Wu BM (2015) Recent advances in 3D printing of biomaterials. $J$ Biol Eng 9: 1-4.

28. Murphy SV, Atala A (2014) 3D bioprinting of tissues and organs. Nature Biotechnol. 32:773-785.

29. Baheiraei N, Yeganeh H, Ai J, Gharibi R, Ebrahimi-Barough S, Azami M, et al. Preparation of a porous conductive scaffold from aniline pentamer-modified polyurethane/PCL blend for cardiac tissue engineering. J Biomed Mater Res A 103: 3179-3187.

30. Minton J, Janney C, Akbarzadeh R, Focke C, Subramanian A, et al. (2014) Solvent-free polymer/bioceramic scaffolds for bone tissue engineering: fabrication, analysis, and cell growth. J Biomater Sci Polym Ed 25: 1856-1874.

31. Pan Z, Qu Z-h, Zhang Z, Peng R, Yan C, et al. (2013) Particle-collision and porogen-leaching technique to fabricate polymeric porous scaffolds with microscale roughness of interior surfaces. Chin J Polym Sci 31:737-747.

32. Johnson T, Bahrampourian R, Patel A, Mequanint K (2010) Fabrication of highly porous tissue-engineering scaffolds using selective spherical porogens. Biomed Mater Eng 2010; 20:107-118.

33. Tran RT, Naseri E, Kolasnikov A, Bai X, Yang J (2011) A new generation of sodium chloride porogen for tissue engineering. Biotechnol Applied Biochem 58: 335-344.

34. Woodruff MA, Hutmacher DW (2010) The return of a forgotten polymer Polycaprolactone in the 21st century. Prog Polym Sci 35: 1217-1256.

35. Webb P (2001) An introduction to the physical characterization of materials by mercury intrusion porosimetry with emphasis on reduction and presentation of experimental data. Micromeritics Instrument Corporation 1-23.

36. Brakebusch C, Fassler R (2003) The integrin-actin connection, an eternal love affair. EMBO J 22:2324-2333.

37. Humphries JD, Wang P, Streuli C, Geiger B, Humphries MJ, et al. (2007) Vinculin controls focal adhesion formation by direct interactions with talin and actin J Cell Biol 179:1043-1057.

38. Altankov G, Grinnell F, Groth T (1996) Studies on the biocompatibility of materials: fibroblast reorganization of substratum-bound fibronectin on surfaces varying in wettability. J Biomed Mater Res 30: 385-391. 